\title{
EVALUATION OF OCULAR PROBLEMS IN HEARING IMPAIRED CHILDREN
}

N. Rama Bharathi' ${ }^{1}$ M.V. Appa Rao².

1. Assistant Professor, Department of Ophthalmology, Andhra Medical College.

2. Professor \& HOD, Department of ENT, Andhra Medical College.

\section{CORRESPONDING AUTHOR:}

Dr. N. Rama Bharathi,

Pratima Paradise, R.K. Branch Road,

Visakhapatnam- 2.

E-mail: ramabharathinela@gmail.com

\section{HOW TO CITE THIS ARTICLE:}

N. Rama Bharathi, M.V. Appa Rao "Evaluation of Ocular Problems in Hearing Impaired Children". Journal of Evolution of Medical and Dental Sciences 2013; Vol2, Issue 25, June 24; Page: 4568-4580.

AIM OF THE STUDY: The present study aimed at evaluation and identification of visual problems is hearing impaired children.

KEY WORDS: Children with hearing disability, ocular disorders, refractive errors, special needs

INTRODUCTION: Hearing handicapped individuals depend on other special senses, especially vision \& tactile sense, in their day to day activities. Hence vision forms an important aspect of Rehabilitation of hearing handicapped. Hearing impairment is difficult as visual impairment, if not more. In the words of famous English novelist HELEN KELLER who was blind as well as deaf hearing impairment is worse than visual impairment, simply because the former leads to social isolation and the individual looses intellectual company. In both hearing and speech are affected, these children also develop MENTAL RETARDATION.

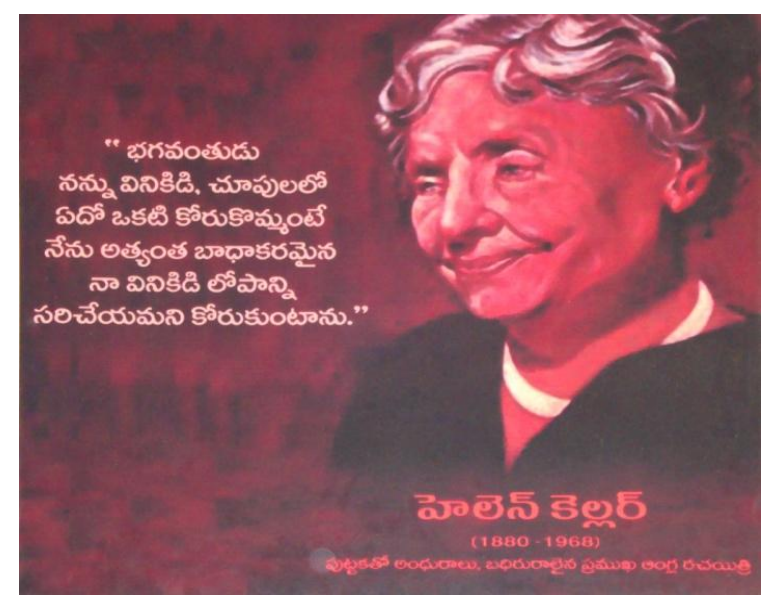

If both hearing and speech are affected, these children also develop MENTAL RETARDATION. 


\section{STUDY ARTICLE}

There have been only two studies of cLDs from India which show that ophthalmic conditions such as refractive errors, strabismus, and nystagmus are common in children with learning disabilities. World Health Organization (WHO) estimates the prevalence of mental retardation in the general population (across all ages) to be $2 \%$, being 3\% in individuals below the age of 18years. Despite the magnitude of the problem, affected individuals are underserved due to a lack of awareness about their problems, even among healthcare providers. All treatable disorders were addressed wherever possible and their effects were noted after a year.

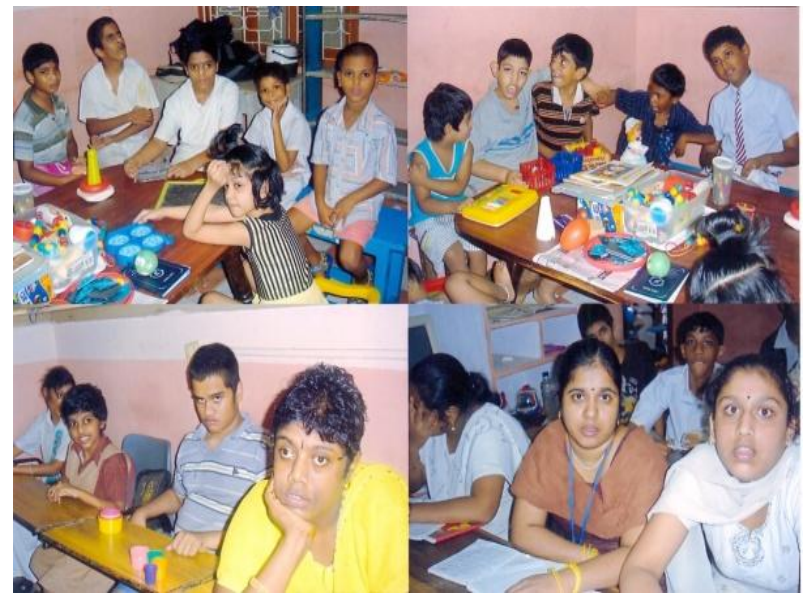

MATERIALS AND METHODS: The study involved 1,053 hearing impaired children with a duration of 01 year from July 2009 to June 2010. The centers included are

1. Govt. ENT Hospital, Visakhapatnam $\quad-614$

2. Special Education Schools for Deaf $\quad-330$

(Srikakulam, Vizianagaram, Visakhapatnam \& Godavari Districts.)

3. Dr.R.S.P.R. Govt. Regional Eye Hospital $\quad$ - 109

Visakhapatnam

Permission was sought and obtained from the principals of special education schools for the hearing impaired.

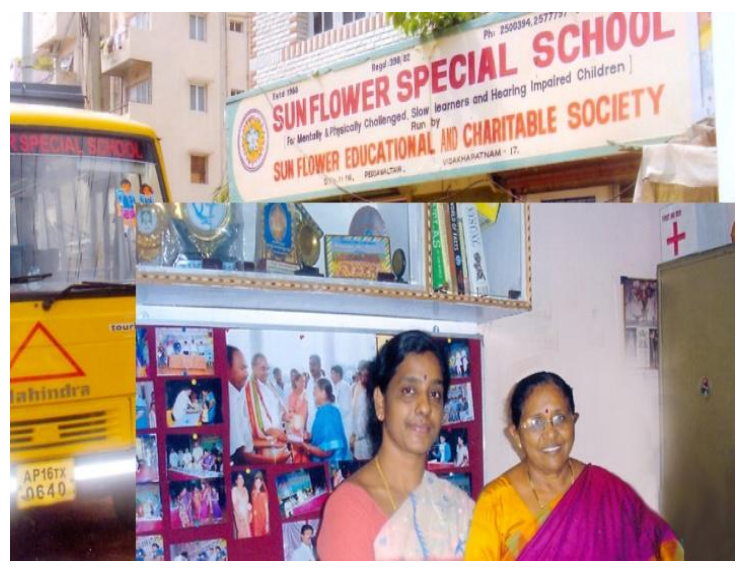

Journal of Evolution of Medical and Dental Sciences/ Volume 2/ Issue 25/ June 24, 2013 Page 4569 


\section{STUDY ARTICLE}
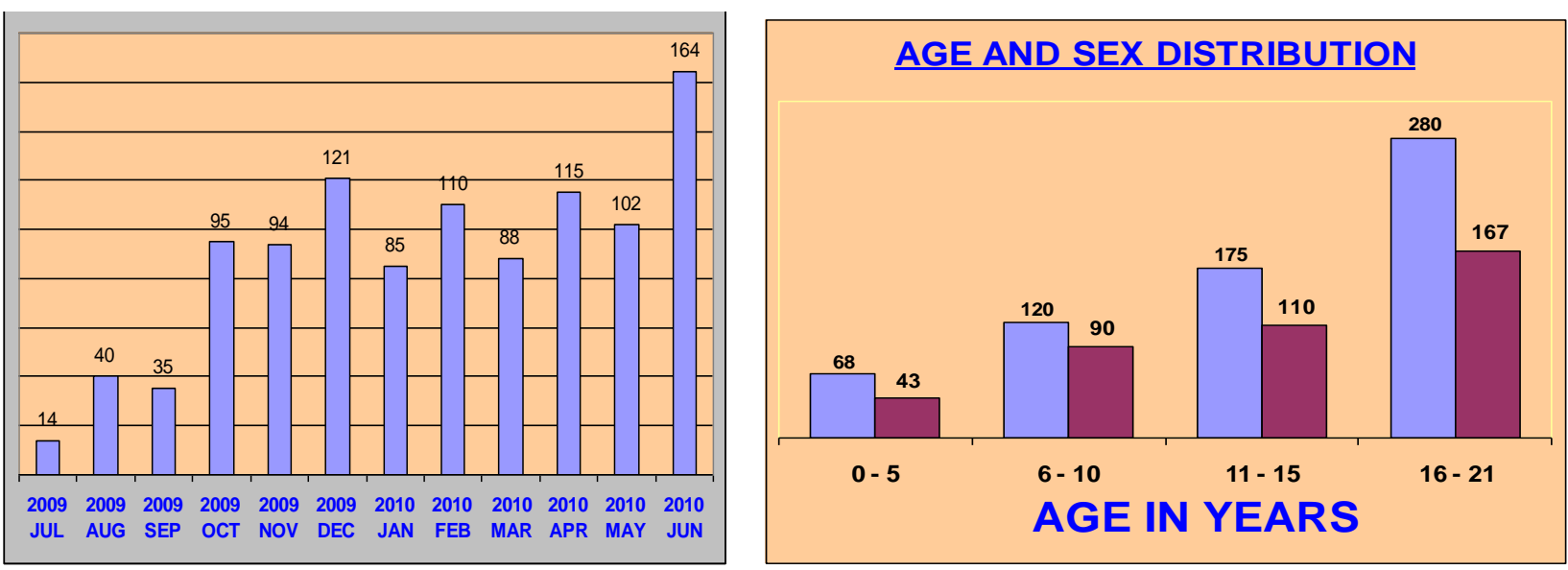

Permission was sought and obtained from the Principals of special education schools for the hearing impaired.

The examination process was explained to the teachers and their assistance was requested. Teachers and parents were asked to notify the examination team if they had noticed any of the following: the child holds his/here work very close or sits close to the blackboard; squint; drooping eyelids; red eyes; habitual eye rubbing or poking; white spots in the eyes; history of night blindness; had spectacles that had been prescribed previously or any other eye health problem.

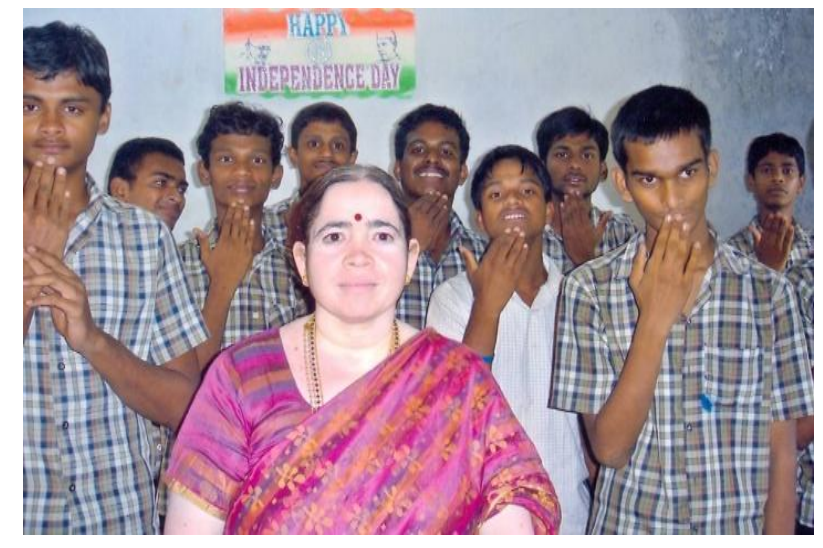




\section{STUDY ARTICLE}

Even though these children suffer form severe sensory neural loss in both ears attempt has been made to quantity the hearing loss.

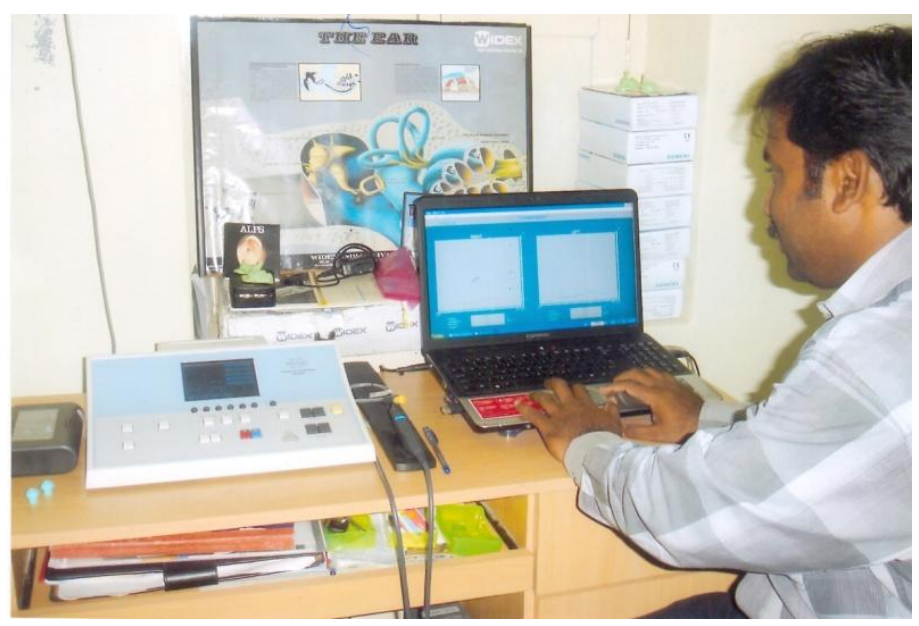

Children in whom retinal pathology was suspected were examined by indirect opthalmoscopy after dilating the pupils. The need for low- vision devices was assessed by a specialist importance of environment modification, especially in relation to contrast and color, was explained to the teachers.

\section{CLINICAL EXAMINATION BY}

- Visual acuity assessment

- Anterior segment examination.

- Pupillary evaluation

- Ocular motility examination

- Alternate cover test

- Fundus examination

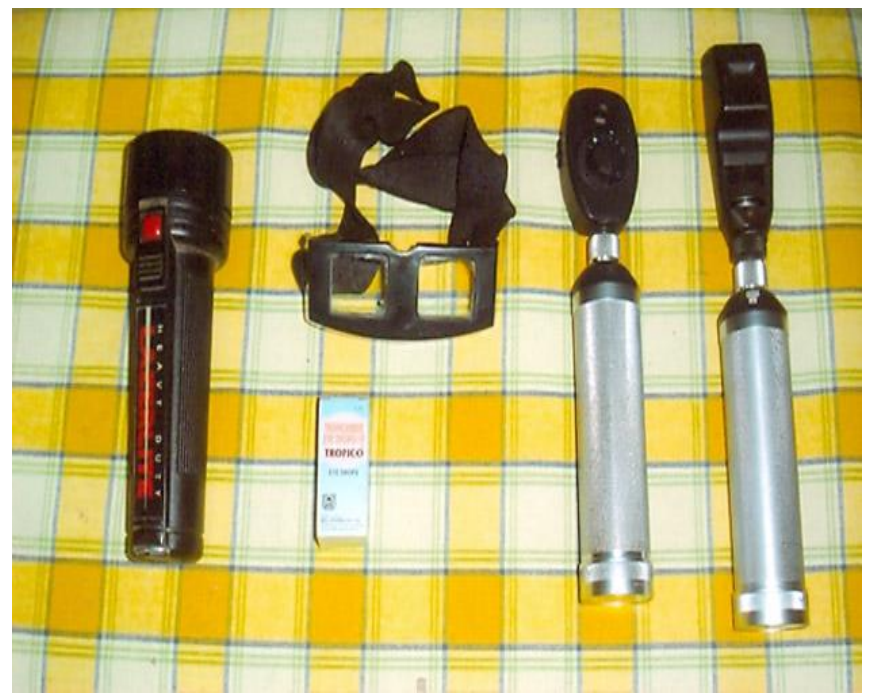




\section{STUDY ARTICLE}

1. Snellen's Chart was used for examining children over five years of age.

2. Near- vision testing was done first, and then visual acuity at six meters was examined.

3. Each eye was tested separately.
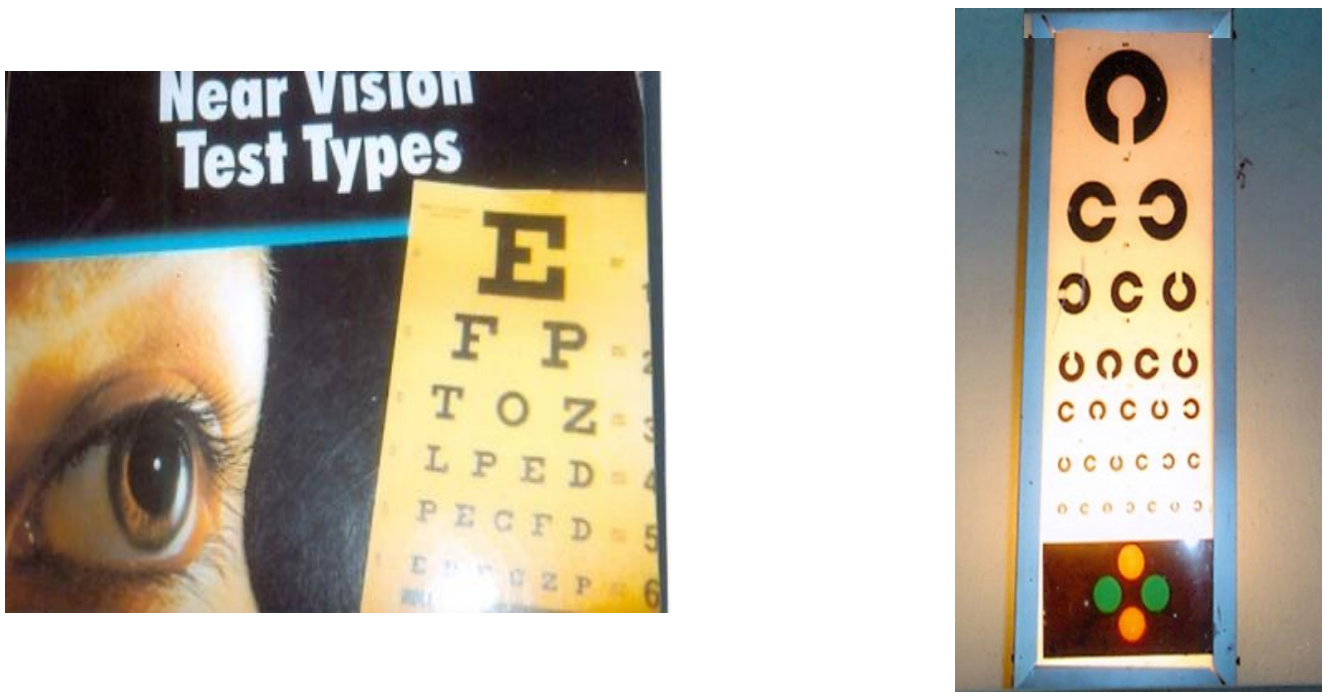

4. Automated Refractometer was used to estimate Refractive Errors

5. Cycloplegic refraction was done where indicated
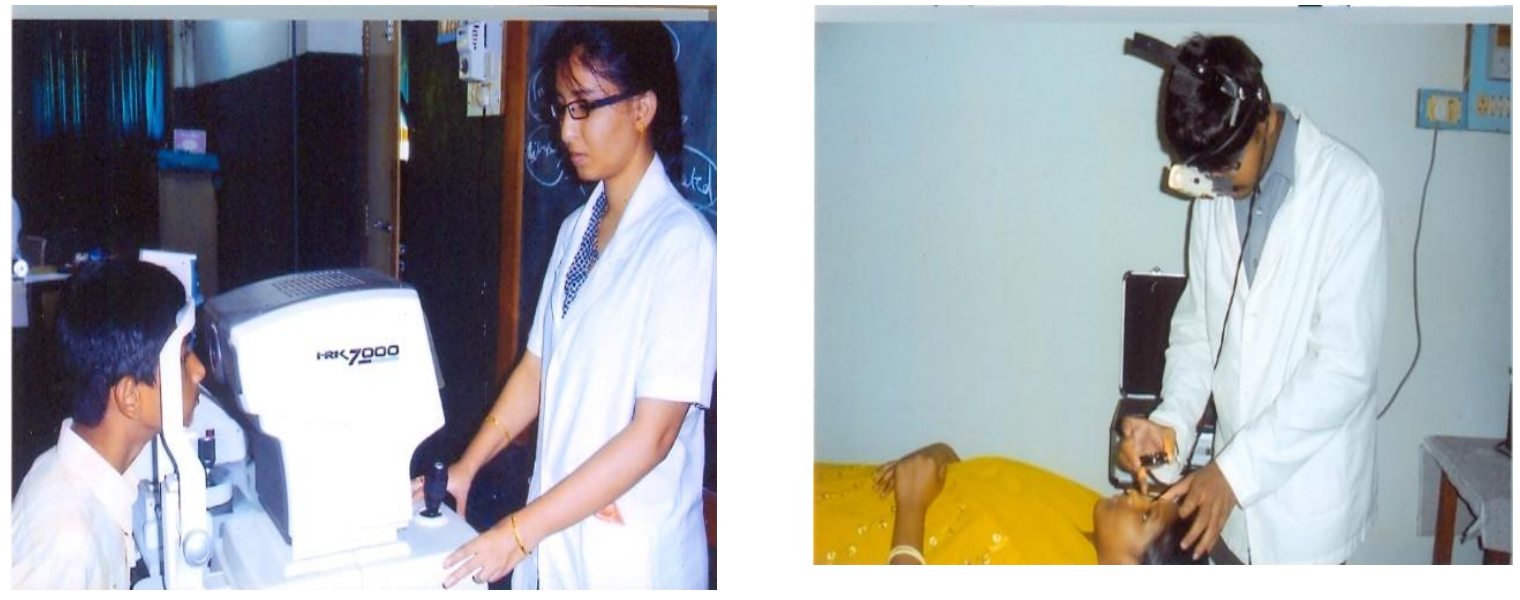


\section{STUDY ARTICLE}

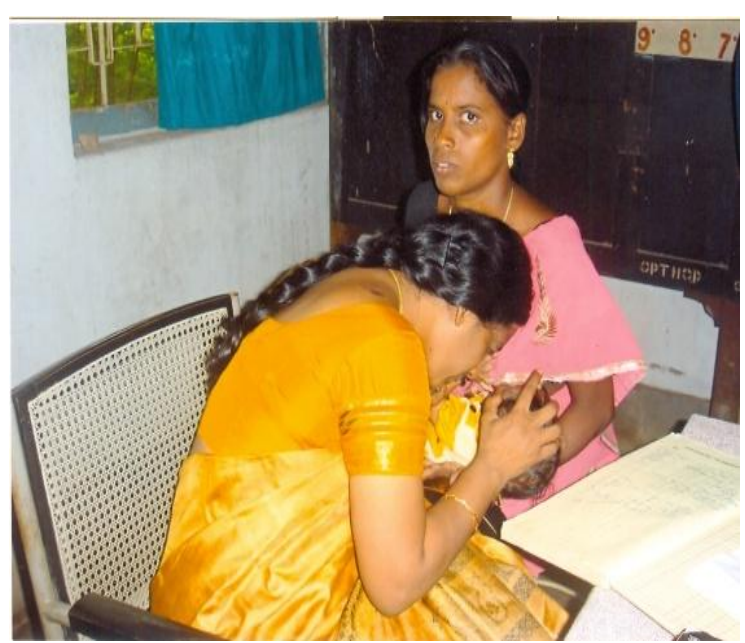

Children who needed more detailed evaluation were referred to the DR. RSPR GOVT. REGIONAL EYE HOSPITAL'S Pediatric Ophthalmology department.

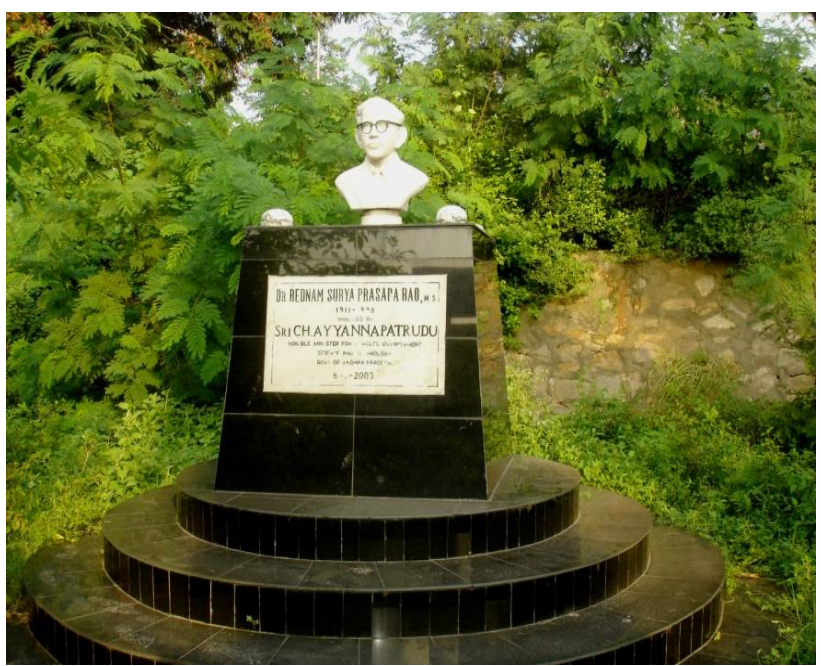

\section{Fundamental Aspects Like}

- H/O CONSANGUINITY

- $\quad$ H/O BIRTH TRAUMA

- H/O FAMILIAL CONGENITAL DEFORMITIES

- H/O DELAYED MOTOR MILESTONES

I have been considered in the study. 


\section{STUDY ARTICLE}
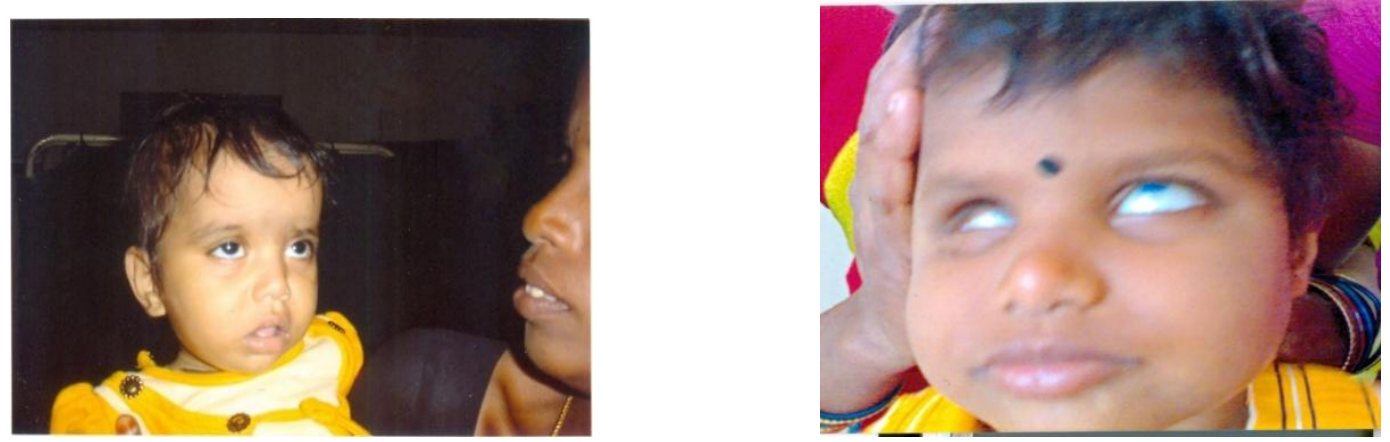

RESULTS : The study involved 1,053 hearing impaired individuals up to 21 years of age, mostly children in one year duration from July 2009 to Jun 2010.

\section{VISUAL ACUITY}

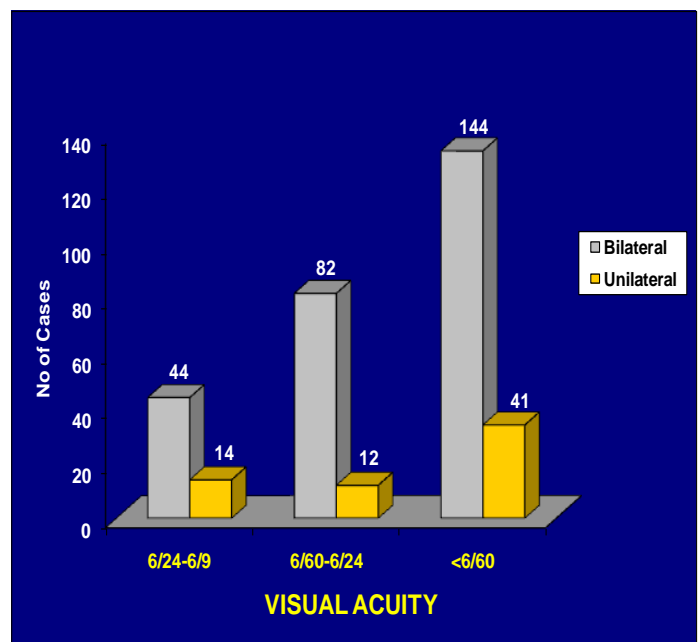

\section{COMMON OCULAR PROBLEMS}

\section{Refractive Errors ( 26\% ) - 274 Cases}

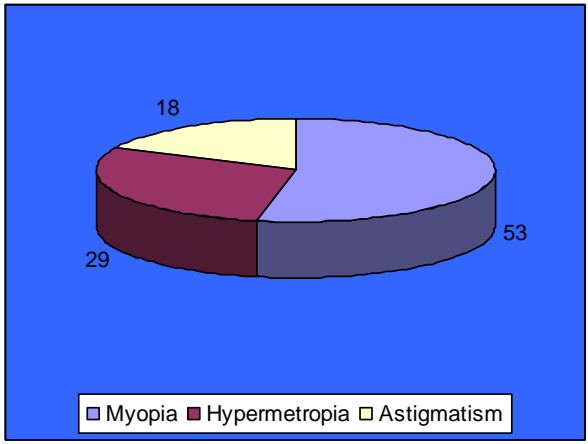

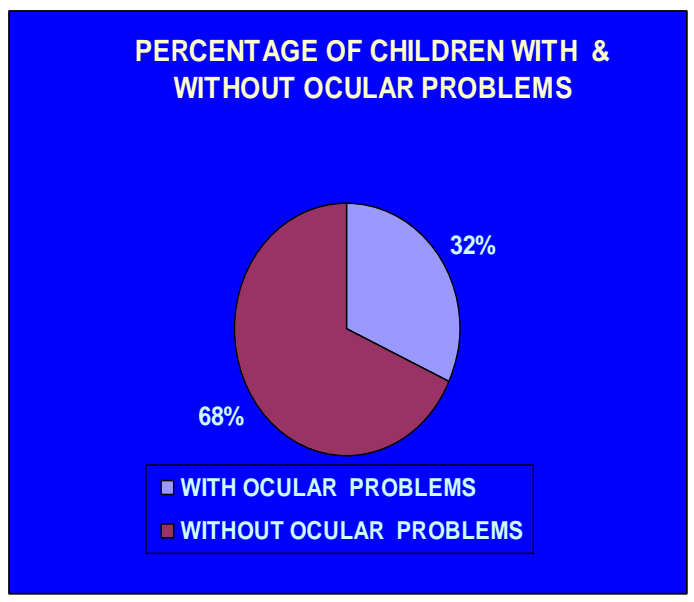

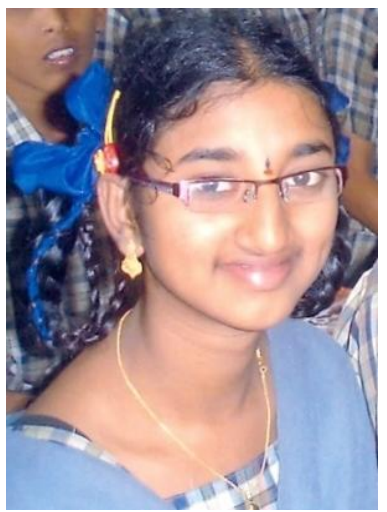




\section{STUDY ARTICLE}
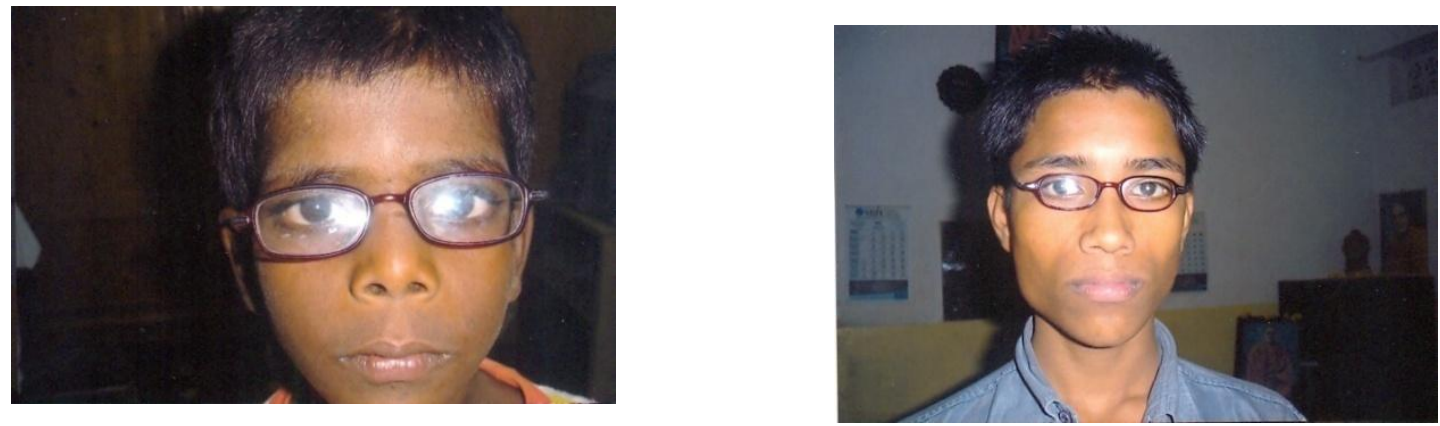

2. Strabismus ( $2.9 \%$ )- 31 Cases
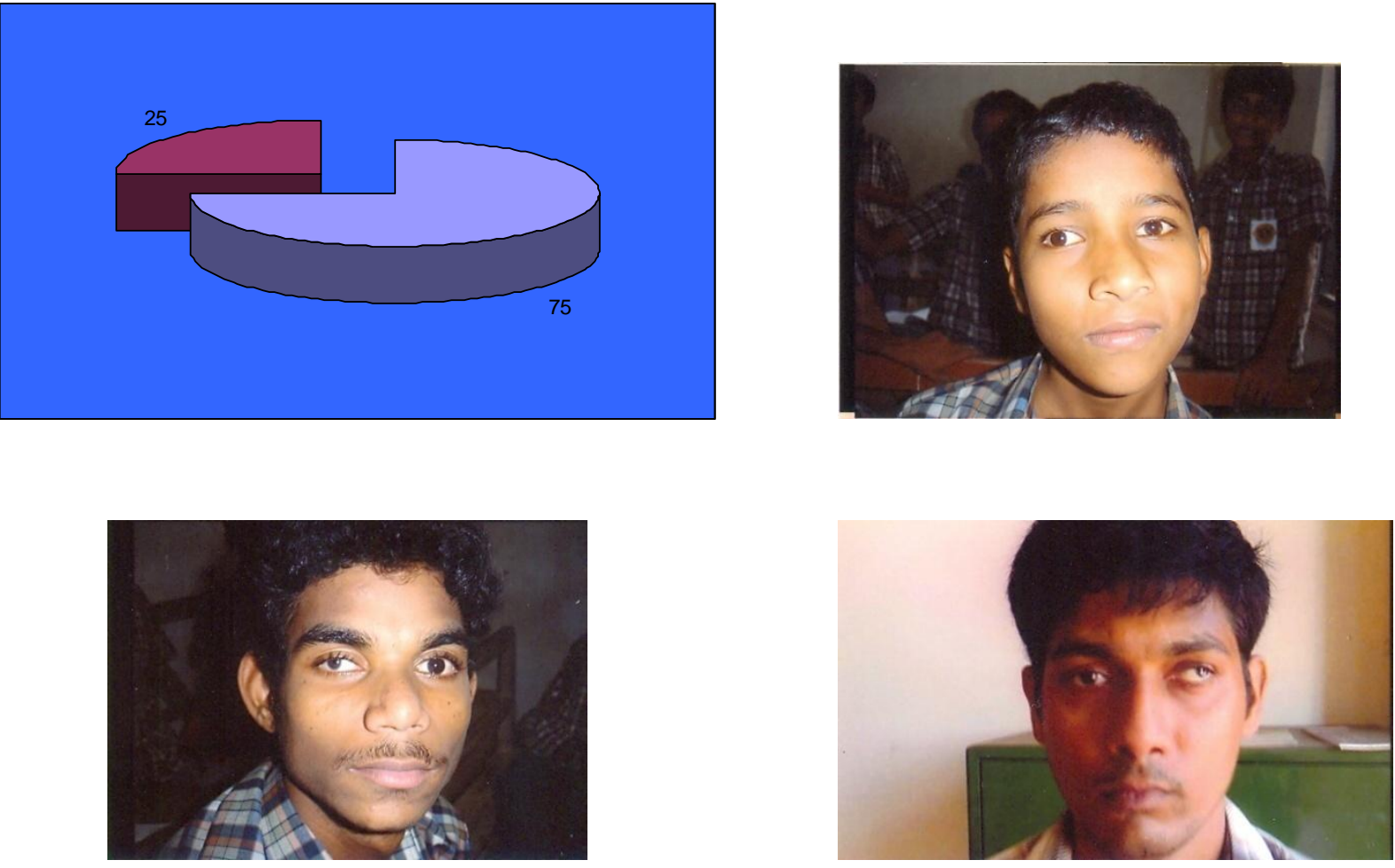

SYNDROMES

\section{GOLDENHAR'S SYNDROME 2 cases (.2\%)}

- Facial asymmetry

- Pre auricular tags

- Hemivertebrae in cervical region

- Epibulbar dermoid

- Coloboma of upper lid

- Mixed or conductive hearing loss

Journal of Evolution of Medical and Dental Sciences/ Volume 2/ Issue 25/ June 24, 2013 Page 4575 


\section{STUDY ARTICLE}
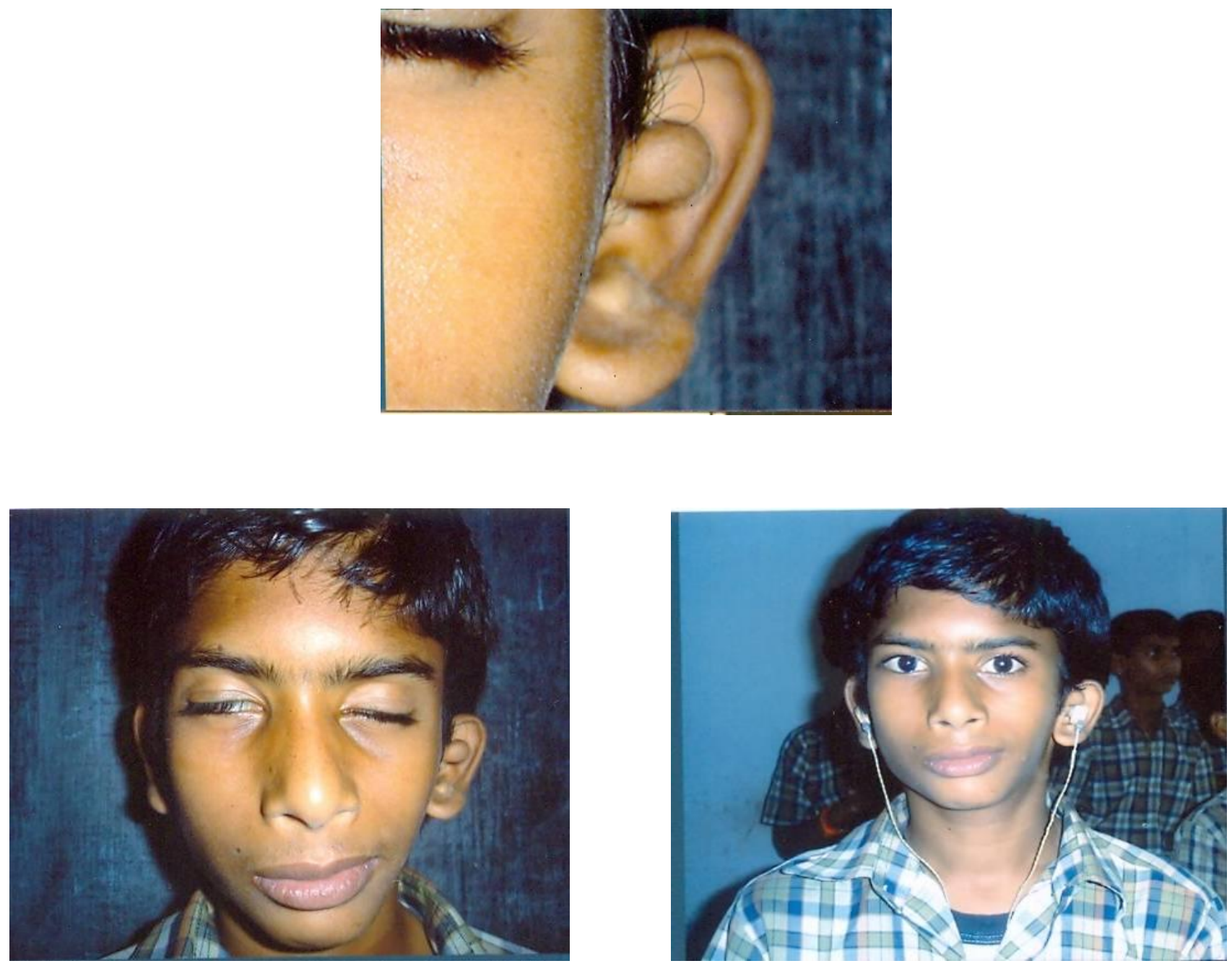

\section{STICKLER SYNDROME 1 case $(.1 \%)$}

- Cleft palate

- Myopia

- Juvenile on set arthritis

- Conductive/ Sensory neural deafness 


\section{STUDY ARTICLE}

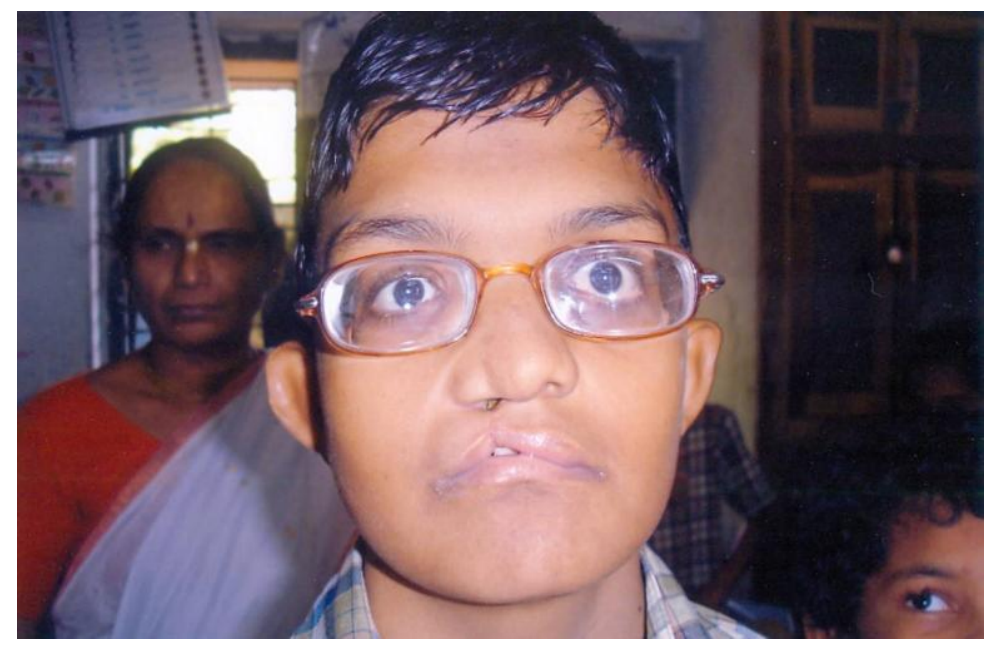

BARDET BIEDL SYNDROME 2 cases (0.2 \%)

Short stature

Truncal obesity

Intelligence is sub normal

Hypogenitalism

Pigmentary retinopathy

Sensory neural deafness

Polydactyly/ The fingers are thick but taper to fine tips

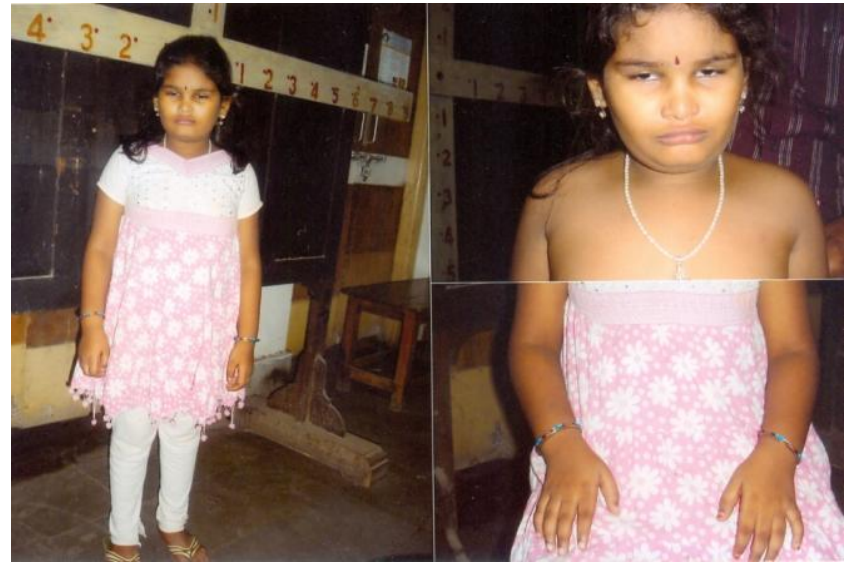

\section{RUBELLA SYNDROME 1 case (.1\%)}

- Congenital cataract

- Neurosensory hearing loss

- Congenital heart disease

- Microphthalmos

Journal of Evolution of Medical and Dental Sciences/ Volume 2/ Issue 25/ June 24, 2013 Page 4577 


\section{STUDY ARTICLE}

- Rubella retinopathy
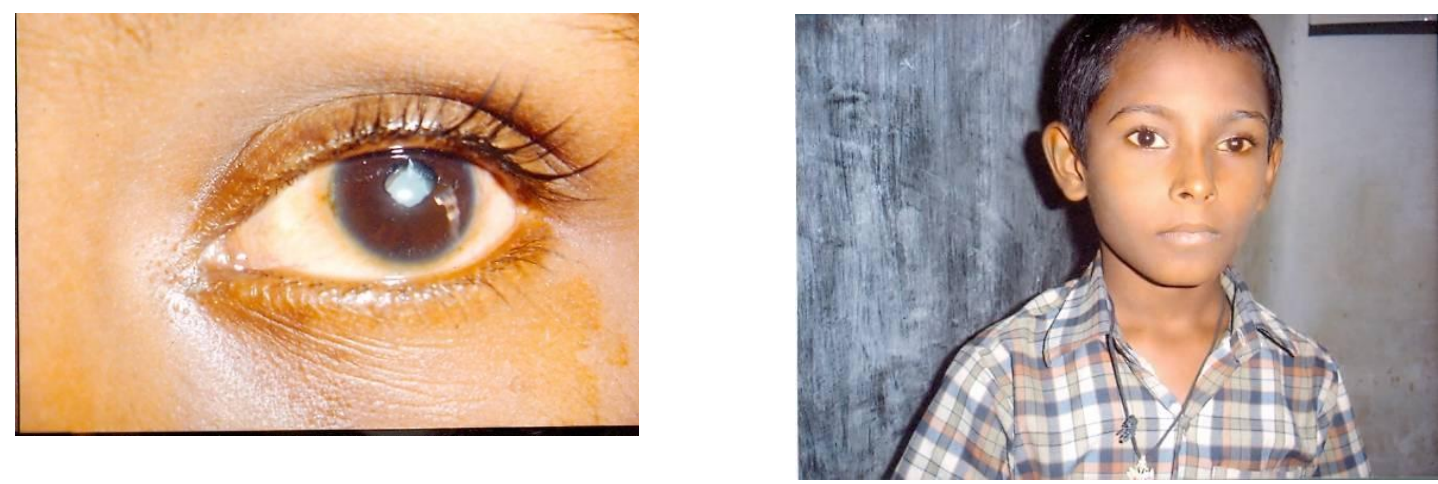

DOWN'S SYNDROME 3 cases ( $0.3 \%)$

- Mongoloid obliquity to palpebral fissures

- Epicanthus

- Refractive error (Myopia)

- Mental deficiency

- Conductive hearing loss

- Low nasal bridge
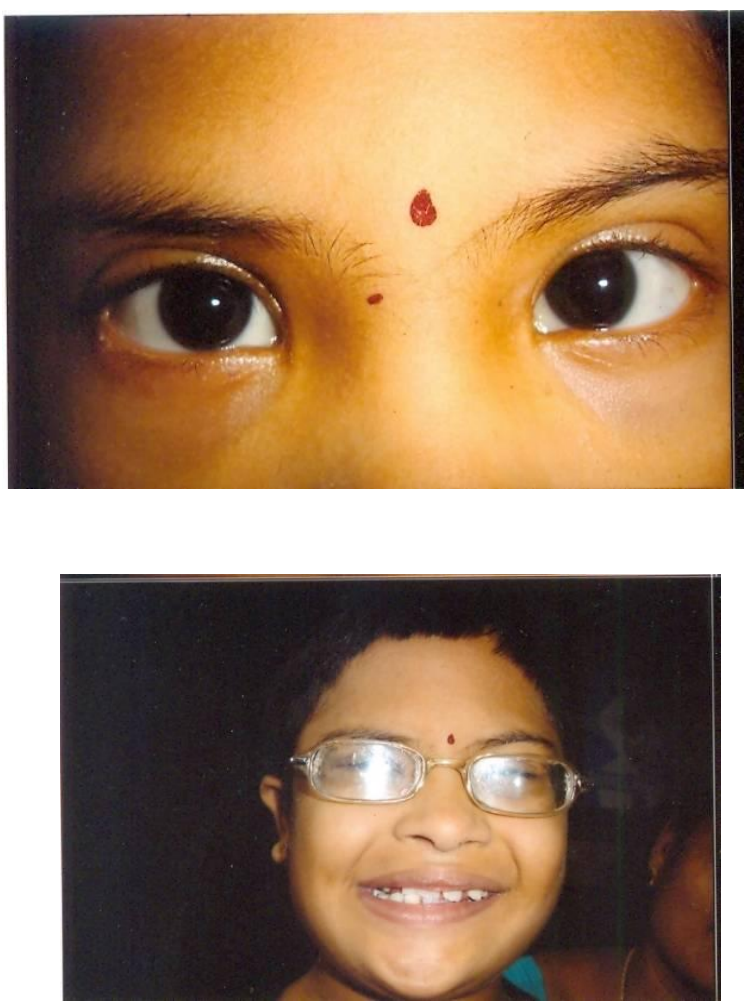

Journal of Evolution of Medical and Dental Sciences/ Volume 2/ Issue 25/ June 24, 2013 Page 4578 


\section{STUDY ARTICLE}

\section{COMPARATIVE STUDY}

\begin{tabular}{|c|c|c|c|c|c|c|c|}
\hline COUNTRY & YEAR & $\begin{array}{l}\text { CHILDREN } \\
\text { EXAMINED }\end{array}$ & $\begin{array}{c}\text { OCULAR } \\
\text { PROBLEM }\end{array}$ & $\begin{array}{c}\text { REFRACTIVE } \\
\text { ERROR }\end{array}$ & USHER'S & FUNDUS & $\begin{array}{l}\text { MOT } \\
\text { ILITY }\end{array}$ \\
\hline U.K. & 2003 & 122 & $\begin{array}{l}110 / 122 \\
(90.1 \%)\end{array}$ & $\begin{array}{c}43 \\
(39.1 \%)\end{array}$ & $\begin{array}{l}6 / 122 \\
(4.9 \%)\end{array}$ & & \\
\hline USA & 1994 & 54 & $33 / 54(61.1 \%)$ & $\begin{array}{l}24 / 54 \\
(44.4 \%)\end{array}$ & - & $\begin{array}{c}3 / 54 \\
(5.5 \%)\end{array}$ & $\begin{array}{c}2 / 54 \\
(3.7 \%)\end{array}$ \\
\hline $\begin{array}{c}\text { INDIA } \\
\text { HV Desai Eye } \\
\text { Hospital } \\
\text { (Pune) }\end{array}$ & 2008 & 901 & $16 / 901(24.0 \%)$ & $\begin{array}{r}167 / 901 \\
(18.5 \%)\end{array}$ & $\begin{array}{l}5 / 901 \\
(0.6 \%)\end{array}$ & $\begin{array}{l}10 / 901 \\
(1.1 \%)\end{array}$ & $\begin{array}{l}12 / 901 \\
(1.3 \%)\end{array}$ \\
\hline $\begin{array}{c}\text { INDIA } \\
\text { Present Study, } \\
\text { Visakhapatnam } \\
\text { (AP) }\end{array}$ & $\begin{array}{r}2009 \\
-2010\end{array}$ & 1053 & $\begin{array}{c}337 / 1053 \\
(32 \%)\end{array}$ & $\begin{array}{c}274 / 1053 \\
(26 \%)\end{array}$ & & $\begin{array}{c}22 / 1053 \\
(2.1 \%)\end{array}$ & $\begin{array}{c}31 / 1053 \\
(2.9 \%)\end{array}$ \\
\hline
\end{tabular}

\section{CONCLUSION:}

1. The Study showed that $32 \%$ hearing impaired children had ocular problems compared to $90 \%$ in UK, $61 \%$ in USA.

Even though the prevalence of ocular problems in deaf-mute children was high in India they remain undetected due to lack of awareness and modern equipment.

2. The most common ocular abnormality is Refractive error.

3. In my Study children who had vision as poor as $6 / 60$ improved to $6 / 9$ after giving corrective glasses.

4. Retinal pigment abnormalities improved to some extent by offering low vision aids.

5. Periodical screening is mandatory. Early detection and intervention of Refractive errors helps in academic and social performance.

\section{ACKNOWLEDGEMENT}

- My thanks are due to my colleagues

- The principals \& teachers of various schools

- Lovely Children of my study 


\section{STUDY ARTICLE}

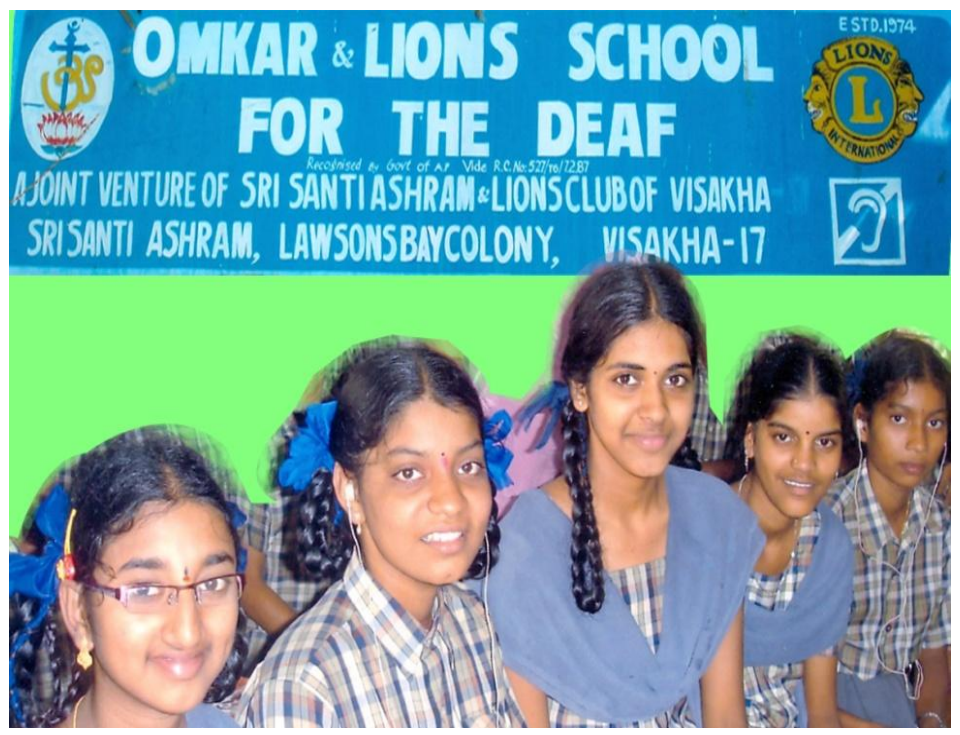

TAKE HOME MESSAGE

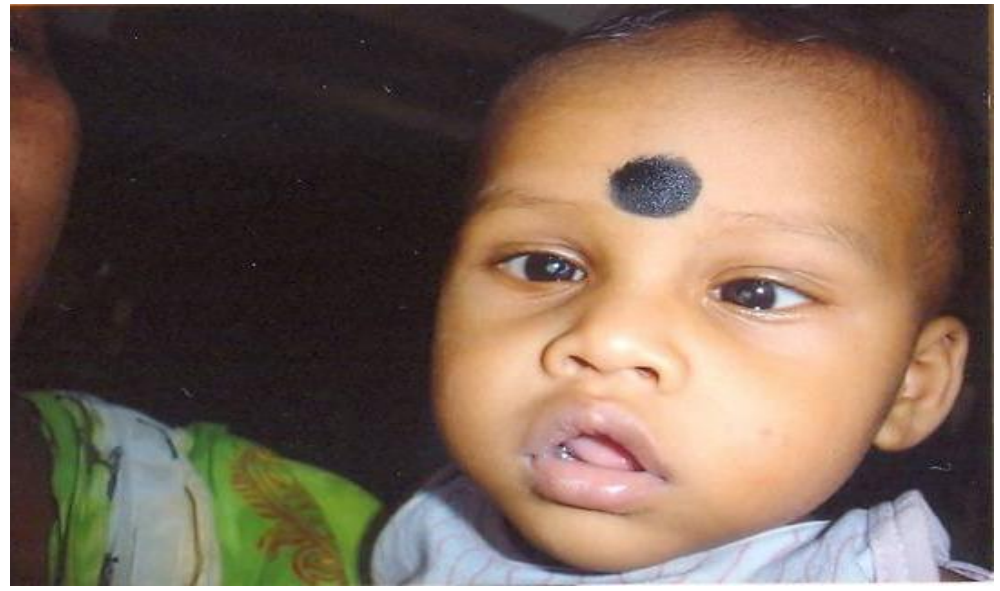

"It is mandatory to rehabilitate hearing impaired children with suitable hearing aids and intensive speech therapy, which involves observing the lip movements. Visual problems if present will jeopardize this rehabilitation process." 